\title{
PENERAPAN KEMAMPUAN METODE EKSPOSITORI UNTUK MENINGKATKAN MOTIVASI DAN KREATIVITAS SISWA PADA MATA PELAJARAN MATEMATIKA
}

\author{
Darmawati \\ SDN 13 Rejang Lebong \\ darmawati@gmail.com
}

\begin{abstract}
ABSTRAK
Penelitian ini bertujuan untuk mengetahui aktifitas siswa terhadap penerapan metode ekspositori dalam pembelajaran matematika serta untuk mengetahui secara langsung hasil peningkatan hasil belajar melalui penerapan metode ekspositori materi operasi hitung bilangan pada kelas IV di Sekolah Dasar Negeri 13 Rejang Lebong. Jenis penelitian ini merupakan penelitian tindakan kelas dengan jumlah subjek penelitian terdiri dari siswa laki 12 orang dan perempuan 18 orang dilaksanakan dalam 3 siklus. Dari hasil penelitian ini diperoleh nilai ratarata skor observasi guru siklus I sebesar 13 , Siklus II sebesar 18, siklus III sebesar 23. Nilai rata-rata observasi siswa siklus I sebesar 13, siklus II sebesar 17, siklus III sebesar 20 dengan kategori baik. Hasil data ketuntasan belajar pada siklusI sebesar 33,3 \% dengan nilai rata-rata 6,46. Pada siklus II ketuntasan belajar $50 \%$ dengan nilai rerata 6,7 meningkat menjadi 7,13 . Simpulan, metode ekspositori dapat meningkatkan motivasi dan kreativitas siswa pada mata pelajaran matematika.
\end{abstract}

Kata Kunci : Metode Ekspositori, Kreativitas, Motivasi Belajar

\begin{abstract}
This study aims to determine the activities of students towards the application of expository methods in mathematics learning as well as to find out directly the results of improved learning outcomes through the application of expository methods of numerical counting operations in class IV in Rejang Lebong Public Elementary School 13. This type of research is a classroom action research with the number of research subjects consisting of 12 male students and 18 people in 3 cycles. From the results of this study, the average score of the teacher observation cycle I is 13, Cycle II is 18, cycle III is 23. The average value of student observation cycle I is 13, cycle II is 17, cycle III is 20 with good categories. The results of learning completeness data in the cycle were $33.3 \%$ with an average value of 6.46. In cycle II the learning completeness was 50\% with an average value of 6.7 increasing to 7.13. Conclusion, the expository method can increase students' motivation and creativity in mathematics.
\end{abstract}

Keywords: Expository Method, Creativity, Learning Motivation 


\section{PENDAHULUAN}

Di era globalisasi ini pendidikan merupakan kunci penting dalam perkembangan zaman sekarang ini. Oleh karena itu peserta didik perlu dipersiapkan untuk mengenal, memahami dan menguasai ilmu pengetahuan dalam rangka meningkatkan kualitas hidupnya (Winaputra, 2003). Upaya untuk mempersiapkan hal itu memang sudah dilakukan melalui pendidikan formal sesuai dengan UU No.20 Tahun 2003 pendidikan formal adalah jalur pendidikan yang terstruktur dan berjenjang yang terdiri atas pendidikan dasar, pendidikan menengah dan pendidikan tinggi (Bandhi, 2010)

Pendidikan sekolah dasar merupakan salah satu dasar dari pendidikan formal yang merupakan dasar dari peserta didik untuk mendapatkan pengetahuan, terutama pelajaran matematika siswa sekolah dasar diarahkan untuk memperoleh pemahaman yang lebih mendalam tentang pelajaran matematika yang dijadikan sumber belajar bagi siswa untuk dapat mengenal dan mengerti tentang berhitung, karna manusia hidup tidak terlepas dari berhitung dalam penyesuaian hidup sehari-hari dan perkembangan zaman ini (Azhar, 2012)

Namun pada kenyataan siswa banyak yang kurang menyukai pelajaran matematika disekolah dan hal ini menibulkan dampak yang kurang baik untuk dirinya sendiri maupun untuk orang lain terutama dikelas 4 Sekolah Dasar Negeri 13 Rejang Lebong. Siswa banyak yang kurang memahami materi yang disampaikan guru sehingga siswa didalam kelas mencari kesibukan sendiri dan tidak memperhatikan pelajaran untuk itu guru kelas 4 khususnya pada mata pelajaran matematika harus dapat mengunakan metode yang sesuai dengan materi pelajaran.

Berdasarkan hasil analisis data yang diperoleh di Sekolah Dasar negeri 13 Rejang Lebong Kabupaten Rejang Lebong diketahui rata-rata hasil evaluasi yang dilakukan pada akhir pelajaran kurang memuaskan, dimana ditemukan dari 30 orang siswa lebih dari setengah anak masih mandapat nilai dibawa standar kreteria ketuntasan minimal (KKM). Dalam melaksanakan penelitian ini, peneliti dalam mengajar mengunakan metode ekspositori, dengan mengunakan metode ini diharapkan agar anak dapat meningkat prestasi belajar kususnya pada mata pelajaran matematika. Disamping itu dalam proses belajar mengajar diharapkan anak dapat lebih aktif lagi dalam mengikuti pelajaran.

Menyikapi kondisi tersebut diatas maka peneliti berkolaborasi dengan teman sejawat untuk mengaktifkan siswa didalam mengkuti pelajaran. Peneliti mencoba sesuatu alternatif dalam mengabil keputusan untuk memotivasi anak dalam kereatifitas belajar (2009). Melalui model eksositori sebagai upaya dalam meningkatkan hasil belajar siswa pada mata pelajaran matematika dikelas 4 Sekola Dasar Negeri 13 Rejang Lebong. Peneliti memilih model pembelajaran ini diharapkan siswa dapat ikut serta secara aktif dan bersemangat dalam mengikuti 
kegiatan belajar mengajar. Daya ingat siswa terhadap suatu pelajaran akan dapat diingat karna siswa terlibat langsung daqlam proses kegiatan belajar mengajar.

\section{METODE PENELITIAN}

Subjek penelitian ini adalah guru, teman sejawat dan siswa kelas IV Sekolah Dasar Negeri 13 Rejang Lebong Kabupaten Rejang Lebong yang berjumlah 30 orang terdiri dari 18 orang perempuan dan 12 orang laki-laki, Perbaikan pembelajaran ini dilaksanakan pada tanggal 12 November 2017. Jadawal pelaksanaan pembelajaran untuk setiap mata pelajaran adalah sebagai berikut :

Tabel 1

Jadwal Pelaksanan Perbaikan

\begin{tabular}{ccccc}
\hline No & Tempat & Tanggal & $\begin{array}{c}\text { Mata } \\
\text { Pelajaran }\end{array}$ & Siklus \\
\hline 1 & SDN 13 Rejang Lebong & 28 Okt 2017 & Matematika & Pra Siklus \\
\hline 2 & SDN 13 Rejang Lebong & 29 Okt 2017 & Matematika & Siklus I \\
\hline 3 & SDN 13 Rejang Lebong & 11 Nov 2017 & Matematika & Siklus II \\
\hline 4 & SDN 13 Rejang Lebong & 18 Nov 2017 & Matematika & Siklus III \\
\hline
\end{tabular}

Penelitian Tindakan Kelas ini dilaksanakan dikelas IV Sekolah Dasar Negeri 13 Rejang Lebong yang menjadi guru dalam penelitian ini adalah peneliti dan dibantu oleh teman sejawat, sedangkan siswa merupakan sempel dalam pelaksanaan pembelajaran. Teman sejawat melihat dan menilai didalam pelaksanan penelitian ini, guna menilai apa saja yang dilaksanakan oleh peneliti didalam pengajaran, apakah masih terdapat kekurangan yang harus diperbaiki dalam penyampaian materi untuk kemajuan disetiap mata pelajaran matematika yang diajarkan.

Penelitian Tindakan Kelas (PTK) ini dilaksanakan dalam III (tiga) siklus dengan 3 kali pertemuan, tiap siklus dilaksanakan sesuai dengan refleksi dari siklus sebelumnya untuk memperbaiki pembelajaran selanjutnya. Setiap siklus nya terdiri dari: 1) perencanaan perbaikan pembelajaran; 2) pelaksanaan menetukan langkah-langkah perbaikan pembelajaran; 3) observasi/pengamatan pelaksanan tindakan dan pengamatan; 4) refleksi.

Hasil data tes siswa dianalisis dengan melihat rerata secara klasikal kemampuan siswa dan digunakan rumus:

$$
X=\frac{\sum x}{N} x 100 \%
$$


Keterangan :

$\mathrm{x} \quad=$ nilai rata-rata pada setiap siklus

n = banyaknya siswa

Proses pembelajaran dikatakan berhasil secara klasikal apa bila siswa dikelas memperoleh nilai 7 keatas atau sebanyak $85 \%$. Sedangkan untuk data observasi prosentase belajar siswa ditentukan dengan menggunakan persamaan berikut: Ketuntasan belajar klasikal $=\frac{\sum \text { siswa yang tuntas belajar }}{\sum \text { siswa }} \times 100 \%$

Tabel 2

Interval Daya Serap Klasikal

\begin{tabular}{ccc}
\hline No & Interval & Keterangan \\
\hline 1 & $0-39 \%$ & Sangat rendah \\
\hline 2 & $40 \%-59 \%$ & Rendah \\
\hline 3 & $60 \%-74 \%$ & Sedang \\
\hline 4 & $75 \%-84 \%$ & Tinggi \\
\hline 5 & $85 \%-100 \%$ & Sangat Tinggi \\
\hline
\end{tabular}

\section{HASIL PENELITIAN}

Pada pra siklus hasil penilaian belajar siswa dilakukan diakhir pelajaran dengan mengunakan 5 (lima) soal essay matematika, didapatkan rerata siswa 5.76 dengan ketuntasan belajar klasikal 20\%, sedangkan rerata hasil belajar dan ketuntasan belajar klasikal siklus I, siklus II, dan siklus III sebagai berikut:

Tabel 3.

Tabel rerata hasil belajar dan ketuntasan belajar pada siklus I,II, III

\begin{tabular}{cccc}
\hline No & Siklus & Rerata hasil Belajar & Ketuntasan Klasikal(\%) \\
\hline 1 & Siklus I & 6.46 & 33.3 \\
\hline 2 & Siklus II & 6.7 & 50 \\
\hline 3 & Siklus III & 7.13 & 90 \\
\hline
\end{tabular}

Berdasarkan hasil observasi penerapan metode ekspositori dapat meningkatkan motivasi dan aktivitas belajar siswa didapatkan hasil cukup baik.

\section{PEMBAHASAN}

Berdasarkan data rerata hasil belajar siklus I,II, dan III menunjukkan peningkatan yang cukup baik terutama dari siklus II ke siklus III.Hal ini dikarenakan guru menerapkan hasil refleksi pada setiap siklus. Pada siklus I, 1) melakukan persepsi dan menyampaikan tujuan pembelajaran; 2) menjelaskan materi pelajaran; 3) menyiapakan media pembelajaran; 4) melakukan Tanya jawab pada siswa untuk meningkatkan pemahaman siswa pada materi pelajaran; 5) memberikan soal latihan; 6) memeriksa hasil latihan siswa dan membahas soal 
latiahan. Pada siklus I didapatkan hasil kriteria aktivitas cukup baik. Terdapat kekurangan pada aspek menyimak penjelasan guru dan menarik kesimpulan.

Pada siklus II, Obervasi aktivitas siswa selama proses pembelajaran di peroleh rata-rata skor 17 dengan kriteria cukup, Hasil observasi aktivitas siswa di atas telah menunjukan kreteria cukup, aspek penilaian yang dilakukan pengamat yang belum berjalan dengan baik (dengan kreteria cukup) beberapa aspek tersebut adalah: 1) siswa menyimak penjelasan dari guru; 2) siswa menarik kesimpulan; 3) siswa mencatat materi pelajaran; 4) perhatian siswa terpusat pada materi pelajaran. beberapa hal yang belum cukup memuaskan. Berdasarkan hasil pada siklus II didapatkan hasil refleksi didapatkan kelebihan sebagai berikut, 1) rencana perbaikan perbaikan sudah cukup; 2) peneliti dalam penguasan materi pembelajaran sudah baik yang disampaikan berurutan; 3) peneliti sudah mengunakan media sehingga siswa dapat mengikuti pelajaran; 4) siswa sudah mulai aktif mengikuti proses kegiatan belajar mengajar; 5) peneliti membahas soal evaluasi. Sedangkan kekurangan yang harus diperbaiki pada siklus III adalah, 1) pada saat menjawab pertanyaan siswa rebut sehingga siswa yang belum mengerti hanya diam dan tidak memberi tanggapan; 2) siswa belum terbiasa untuk bertanya dan memberi tangapan dalam pembelajaran.

Pada siklus III, Observasi aktivitas siswa selama proses pembelajaran di peroleh rata-rata skor 20 dengan kreteria baik, hasil observasi aktivitas siswa di atas telah menunjukan kreteria baik, aspek penilaian yang dilakukan pengamat yang belum berjalan dengan baik (dengan kreteria cukup) beberapa aspek tersebut adalah siswa mencatat materi pelajaran.

\section{SIMPULAN}

Hasil penelitian menunjukkan rerata hasil belajar terjadi peningkatan pada setiap siklus dan aktivitas belajar menunjukan peningkatan yang cukup signifikan. Dengan demikian penerapan metode ekspositori dapat meningkatkan motivasi belajar dan kreativitas belajar siswa dalam belajar matematika.

\section{DAFTAR PUSTAKA}

Arsyad, A. (2011) Media Pembelajaran.Jakarta; PT. Rajagrafindo Persada.

Delphie, B. (2010). Pembelajaran Anak Tunagrahita, Bandung: PT Refika Aditama.

Dimyati \& Mudjiono.(2009) Belajar dan Pembelajaran.Jakarta; CV Rineke Cipta.

Menteri Pendidikan Nasional Republik Indonesia (2003), Undang-undang Republik Indonesia Nomor 20 Tahun 2003 Tentang Sistem Pendidikan

Nasional Beserta Penjelasannya, Jakarta: Departemen Pendidikan Nasional.

Winataputra. (2003). Strategi Belajar Mengajar. Jakarta: Universitas Terbuka 